\title{
The Paradigm of Proper Wage for Home Base Worker in Indonesian Labor System Based on Fair Wage Theory
}

\author{
Suci Flambonita, Abdul Rachmad Budiono
}

\begin{abstract}
The low appreciation and recognition for workers, particularly home base worker in the labor system in several regions of Indonesia has caused ignorance on their well-being. Their condition requires the attention from all parties including businesspeople, government (executive and legislative), and other social institutions. Without the support of other related parties, significant changes on the welfare of home base worker are impossible to take effect. There are several factors that cause the low welfare of home base worker in Indonesia, one of which is wages they receive, far lower from provincial, municipal, and sectoral proper wage standards. Fair wage is defined as equitable wage, in that equitable means consistent, impartial, and unbiased. Wage is closely related to worker's proper life. Standardization of waging system is expected to relieve home base worker from job stress and maintain their socio-economic stability for sustainable development. This study uses sociolegal method, which discusses phenomena in the society, developed and institutionalized into legislations in a coherent rule of law. Using statute, conceptual, and case approach, the prescriptive analysis of this study uses fair wage theory as a guideline and parameter of proper wage for housemaids. In order to create welfare for home base worker in Indonesia, particularly regarding wage, regulations that govern minimum wage are required. For housemaids, wage is a source of income to be used for fulfilling their daily needs properly and equitably to create prosperous society according to Indonesian constitutional mandate based on the nation's philosophy that had been stated as the foundation of the state, which is Pancasila.
\end{abstract}

Index Terms: Fair, home base worker, Paradigm, Proper wage labor.

\section{INTRODUCTION}

Although the number of home-based workers in several regions in Indonesia is high, the legal recognition to them in Indonesian economic system is still low; their fate is still neglected. They are make the putting out system ( (1) (2)), and the established work pattern is subordinative relationships (3). Home-based workers deserve the attention from all parties: entrepreneurs, government (executive and legislative), and other social institutions. Regulations for home-based workers are based on improper conditions in terms of wages and social security (4). Without the support

Revised Manuscript Received on September 22, 2019.

Suci Flambonita, Doctoral Student, Faculty of Law, Brawijaya University, Malang, Indonesia and Lecture Faculty of Law Sriwijaya University, Palembang, Indonesia, uciebaeh@gmail.com

Abdul Rachmad Budiono, Promoter, Faculty of Law Brawijaya University, Malang, Indonesia, Rachmad.budiono@ub.ac.id

from all stakeholders, significant changes to the welfare of home-based workers are difficult to achieve. In 2016 Bitra Indonesia organized at least 1,465 home-based workers.

Home-based workers work independently, without superiors and subordinates, because those who work alone at home are not paid based on working hours but based on the specific amount of product they come up with (5).

To provide a proper wage for home-based workers in Indonesia, legislations governing "wages" were made( (6), (7), (8))because wages are their source of income to fulfill their needs in an equitable manner. Global trade and investment patterns are currently having a dramatic impact on employment relations and other market transactions (9).Home-based workers produce goods for companies in the value chain, both national and global ones, (10) to create a prosperous society as mandated by the constitution and the philosophy of Indonesian nation, which is defined as the ideology (grundnorm) of the state, the Pancasila (11).

There are several factors that cause the low welfare of home-based workers in several regions in Indonesia; one of the indicators is the wages they receive (12) (13) (14) (15). Every worker expects receiving wages that can adequately fulfill their and their family's needs based on humanity values.

The data states that the minimum wage and the wage component expected by workers have not been fulfilled (16) (17). They usually express their demand for a proper wage at "May day", which is commemorated every year; a demand of workers in general. The struggle of workers, especially home-based workers, to get a proper wage is still in vain because their position and legal status are not directly recognized by the government.

The crucial juridical problem that hinder the establishment of a more feasible minimum wage that is able to meet the needs of home-based workers and their families is a strong stigma from employers, as well as the government (legislative and executive), that home-based workers in Indonesia are less educated, unskilled, and less productive, not to mention other negative stigma for workers in Indonesia as a whole, especially those who are home-based. This makes the wage policy system for home-based workers low, below their expectations.

On the one hand, the low wage for home-based workers is the result of the unfair recognition and emplacement of such workers in Indonesian

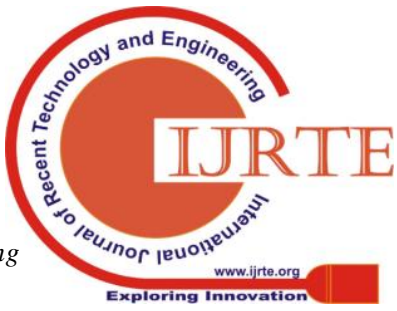


economic system. On the other hand, it is a result of every-year new workforce increase, outnumbering job availability. This condition is more profitable for employers. A worker who refuses low wages from his employer will automatically stop working, or not be given a job. Employers will not be affected by their decision of quitting or resigning because they are not obliged to provide severance pay or other compensation.

The condition above makes the position of home-based workers weak and helpless, being subordinates in their position. Symptoms like this will continue, becoming a permanentized view or labeling that home-based workers are low, unqualified, unskilled, uneducated, unproductive, and so on. Therefore, a more systematic and continuous effort is needed to foster a better awareness in understanding and addressing the existence of home-based workers in several regions in Indonesia, so that the paradigm or thought that positions home-based workers as "low laborers" can be minimized. Home-based workers are people who have rights and obligations. Every human being wants to be humanized through existing policies, including policies related to proper wage.

\section{LITERATURE REVIEW}

Minimum Wage Policy has become an important employment issue in several countries, both developed and developing (18) (17).Regulations made by the government are a form of state's involvement in the field of labor, an effort to protect worker's rights and obligations through legal state-founded norms, public norms that must be guarded from being misleading and misled (19). It is legal morality held firmly through legal protection, which shows that the state has an important role in maintaining and improving the welfare of its people, especially in the field of labor, as a mandate from the constitution, particularly Article 27 paragraph 2 and Article 28D paragraph 2 of Indonesian Constitution (20).

The function of the state is public service based on established impartial mechanisms and rules. The interesting thing about the state's involvement in the legal field regarding employment is the philosophical foundation that makes the state has the right to enter the jurisdiction of labor. "The task of the government in the broadest sense is to carry out policies to meet the objectives of the state government, and the purpose of state government, in essence, is the national goal of the nation" (21). What becomes the problem is the equitable form of labor law system (22).

The national objectives of the state of the Republic of Indonesia are listed in the fourth paragraph of the Preamble of Indonesian Constitution, which reads" to form a Government of the State of Indonesia that shall protect the whole people of Indonesia and the entire homeland of Indonesia, and in order to advance general prosperity, to develop the nation's intellectual life, and to contribute to the implementation of a world order based on freedom, lasting peace and social justice" (23).

Every country has a function that must be accomplished. "Every country carries out some minimum functions that are absolutely necessary; they are 1) enforcing order for stability, in this case the state is a stabilizer; 2) realizing people's welfare and prosperity, and 3) upholding justice and organizing state defense security (23). In regards to the function of the state, there are many policies and actions that must be taken by the state (government), and these policies are very likely to clash with each other, giving an impression that the state interferes with individual rights, including mutual labor agreements. The philosophical reasons for the state to be involved in the world of labor seem to be based on the notion that employment or labor issues concern the lives of many people and the public interest. The function of the state is to implicitly maintain public order and realize public welfare. Therefore, countries should address labor issues. According to Lalu Husni, the involvement of the state (government) in the field of law concerning employment is to "... create fair labor relationship, which is the function and duty of the government" (24). Social justice in people's lives is difficult to achieve because strong parties tend to control the weak ones. It is an adage that the strong and powerful tend to outsmart the weak. Therefore, the weak parties should receive protection from the state.

The policy of proper wage for home-based workers can ideally be made by looking at various sides or spectrum, such as philosophical, normative, historical, economic, and socio-anthropological aspects. Policies made through such a way can prevent various problems in the future. Conversely, if policiesare made based on a single poit of view, it is likely, or it can even be ascertained, that many new problems will arise from the policy, and the negative impact of the new problems can be greater than the existing conditions and problems with the theory of pricing (25)

Based on the above, the discussion about the theory of justice should begin with the understanding that justice is the most important virtue in human life, and therefore the value cannot be exchanged by (or compromised with) any other values. Etymologically, justice in Indonesian is "keadilan", derived from the Arabic words of "adl". In English justice has the same meaning as latin word of " justitia", rooted from the word "jus", which means law or rights. In conjunction with the concept of justice, the word is interpreted as (1) the quality of being righteous, honest; (2) impartial, fair in representing facts, (3) vindictive, rewarding, sound in reasoning, rightful, and valid, and (6) just or lawful. This formulation is in line with what is stated in Black's Law dictionary, which defines "justice" as "the constant and perpetual disposition to render every man his due". Justice is the continuous pemuntukanto give everyone what they are entitled to. A similar understanding is read in the formulation of the Institutes of Justinian, in that "justice is the constant and continual purpose which is given to everyone's own" (26)

Furthermore, John Rawls argued that the value of justice cannot be bargained and must be realized in the society without the necessity of sacrificing the interests of other communities. An injustice is tolerable only when 
it is necessary to avoid an even greater injustice. Therefore, being first virtues of human activites, truth and justice are uncompromising. A detailed discussion about justice was carried out by an ancient Greek philosopher Aristotle (384-322 BC). In his opinion, justice is appropriateness of human actions. Appropriate is the midpoint between two extreme ends, namely too much and too little. Thus, justice in its principle is a kind of balance that includes four elements, which was formulated by Aristotle as follows:

\begin{tabular}{|c|c|c|}
\hline FOR A & $=$ & FOR B \\
\hline JASA/USE A & $=$ & JASA/USE B \\
\hline
\end{tabular}

Thus, Aristotle's theory of justice is based on equality principles. In its modern version, the theory was formulated by Isaiah Berlin with his statement that justice is achieved when same things are treated samely and different things are treated differently. In addition to distributive justice, which is intended for distributing things that must be given to community members according to the specified measure of justice, Aristotle also presented the concept of remedial justice and commercial justice.

According to Aristotle, justice is a virtue related to human relations, and then he memuntuk justice with a model that includes:

a. Distributive justice is identical with justice on the basis of proportional equality, which is giving everyone their rights. The position of equality-based justice is to be a numerical and proportional similarity. The meaning of numerical similarity gives rise to the principle of "all people are equal before the law", while the meaning of proportional equality gives birth to the principle of "giving everyone their right".

b. Corrective or commutive (remedial) justice focuses on amending something wrong, which seeks to provide adequate compensation for the injured party. If an offense is committed, appropriate punishment needs to be given to the offender.

The principle of justice according to John Rawls is specified as follows (27).

a. The fulfillment of equal rights for basic liberties(equal liberties);

b. Economic differences must be governed to create reasonable maximum profits for everyone including for weak (maximum minimorium) and to create opportunities for everyone.

According to John Rawls, justice will be achieved if the even use of goods according to ones' respective personalities is done maximally (justice as fairness). Distributive justice questions how the state or society these resources to people. Vindictive justice requires a balance between achievement and counter-achievement, called justice which provides penalties proportional to the committed crime or violation. Creative justice gives rights to someone based on their creativity in social culture. Legal justice demands compliance with the law.

\section{RESULT AND FINDING}

The main objective of law is to create community order and balance, a shared objective of labor law (28) particularly in relation proper wage. Every social relationship should not contradict with the provisions of applicable legal regulations and norms. Law regulates the balance between rights and obligations of humans as social beings and manifests justice in living with others. Labor law can be seen from two perspectives: labor law definition and labor law philosophy, in which the latter is the basis of the formation of a legal rule that relies on the objectives of labor law, namely to uphold justice.

There have been many paradigm shifts in the wage system in Indonesia, from Minimum Physical Needs to Minimum Living Needs. The change was born from a comprehensive thought evaluation about the policy. After some times of implementation, minimum physical needs paradigm was considered no longer compatible with the development of life. The change from minimum physical needs paradigm to minimum living needs paradigm, of course, has gone through in-depth evaluations, covering all aspects of the consequences, and the new paradigm was considered the best to be applied. However, the shift of labor from informal market to formal market is possible. This happens when employment opportunities are re-created in the formal market, which invites workers in informal market to get better wages (18). Based on the Explanation of Draft Law Number 13 of 2003 concerning Employment Development and Protection in Article 102

1. It is stated that the formulation of wage structure and scale is to be used as a guideline for wage setting so that each worker gets wage certainty and as a means to reduce wage gap between the lowest and highest in concerning companies;

2. Wage review is carried out to offset the price of living needs, work performance, and company development and capabilities.

Based on the description above, home-based workers need to be given legal protection in accordance with their rights and obligations as other formal workers. Article 1 paragraph 3 of the Indonesian Constitution clearly states that Indonesia is based on law. Therefore, there is no bargaining or other alternative that law state principle must be truly implemented. Indonesia as a law state means that all actions, whether carried out by the people or the authorities, must be based on applicable law. Everything must be based on legal provisions. The state welfare law theory is used to provide legal protection for every citizens, including providing legal protection for home-based workers in obtaining jobs and rewards fairly and properly in employment relations.

Legal protection provided by states is the responsibility of legal states to its people, in addition to realizing prosperity and providing legal protection for their citizens. Therefore, in the implementation of law state principle regarding the implementation of national development, labor has an important role and position as an actor of national

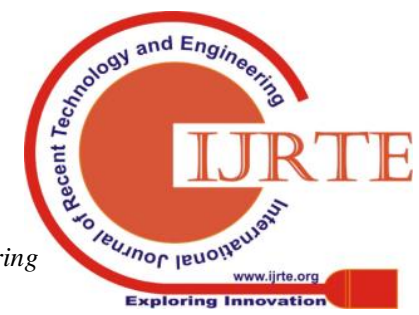


development objectives. Legal protection for home-based workers is intended to ensure that their rights are equal to the rights of other formal workers. This legal protection is intended to ensure all basic rights for the welfare of workers and their families by maintaining the development of business world. Employment, in its implementation, must fulfill basic rights and protections for labors and workers, and at the same time must create a conducive environment for the development of the business world. Based on these considerations, the inherent rights of home-based workers must be protected as the rights of formal workers in general, particularly for individually and socially proper wage (6)

The principle of right equality to obtain employment and fair treatment from employers is contained in Article 27 paragraph 2 and Article 28D paragraph 2 of Indonesian Constitution. The two articles state that every citizen has the right to get a job and get compensation fairly and properly from a work relationship. The politics of law is useful to find laws suit expectations and reality (das sein das sollen), the articles and the implementing regulations, and suit law in book and law in action.

The Labor Act explicitly explains that every worker has the right to get protection for his safety, health, morals and morality, and treatment that is in accordance with human dignity and and religious values. In its essence working relationship between workers (in this case home-based workers) and employers occurs after a work agreement, an agreement that workers are willing to work and get wages or other forms of compensation and employers are willing to provide jobs and wages in accordance with the provisions of labor legislation.

Article 51 of the Labor Act states that "(1) A work agreement takes place because of an agreement between employers and workers; (2) A work agreement that must be in written form is carried out in accordance with the applicable laws and regulations". The meaning contained in Article 51 of the Labor Act is that employment agreements can occur if there is a working relationship between workers and employers, where the agreement is agreed in writing and is an agreement of both parties, namely workers and employers. The straightforward meaning as stated in Article 51 of the Labor Act is not found in the employment agreement for home-based workers. Their work agreement is unwritten, verbally agreed between home-based workers and employers, so the element of Article 51 of the Labor Act does not exist. Meanwhile, Article 52 of the Labor Act states that:

1. A work agreement is made based on:

i. Agreement of both parties;

ii. Ability or competency in carrying out legal actions;

iii. Existence of agreed work; and

iv. Fact that the agreed work does not harm public order, decency, and applicable laws and regulations

2. Work agreements made by the parties, should they violate the provisions referred to in paragraph (1) letters $a$ and $b$, can be terminated;
3. Work agreements made by the parties, should they violate to the provisions referred to in paragraph (1) letters $\mathrm{c}$ and $\mathrm{d}$, are null and void.

The involvement of the state in legal protection for home-based workers is one of the country's responsibilities for the welfare of its citizens. The form of protection, by Imam Soepomo, is said to be a guarantee that workers can do decent work for humanity. One form of the legal protection is a work norm that includes protection of workers related to work time, wage system, rest, leave, decency, worship according to their respective religions and beliefs as recognized by the government, social obligations and work enthusiasm and morale that guarantees high performance as well as treatment according to dignity and morality. Legal protection for workers is very necessary due to their weak position (29).Legal protection from employers will be carried out if the legislation in the field of labor which requires or forces employers to act in accordance with the legislation is truly carried out by all parties. Philipus M. Hadjon (30)argued that the form of legal protection is always related to power. There are two kinds of power that are always the center of attention, namely the power of legal protection for the people (who are governed) against the government (the one who rules). Legal protection for home-based workers is very necessary since their status or legal position is weak (inferior), while the status or legal position of employers is strong (superior).

The responsibility of employer, as described above, if it is associated with the concept of justice or the theory of John Rawls, it can be stated that "Weak parties must be guaranteed a better condition, the employer (superior) must guarantee the worker (inferior), while the party in deficit must get and be given a more chances, and the party in difficulties must be assisted". The legal position of home-based workers is very weak compared to workers in general, so home-based workers must get legal protection as their position as stipulated in the Labor Act.

An achievement in wage regulations confirms that the increase of minimum wage is calculated based on national inflation value and national economic growth (31). In detail, the Minister of Manpower affirmed that the following Provincial Minimum Wage $=$ Current year-provincial minimum wage $+(($ Current year-provincial minimum wage $)$ (inflation + economic growth)). The illustration is as follows: If the current-provincial minimum wage in of West Java is 2,800,000 IDR and inflation and economic growth is $6 \%$ each, the increase in of provincial minimum wage is $2,600,000 \mathrm{IDR}+6 \%$ of $2,600,000 \mathrm{IDR}=156,000 \mathrm{IDR}$, so that the following year-provincial minimum wage is 2,600 $.000 \mathrm{IDR}+156,000 \mathrm{IDR}=2,756,000 \mathrm{IDR}$. The formula of minimum wage increase is adjusted to inflation and economic growth value, so the calculation of the value of needs is adjusted to the economic development.

What should apply to home-based workers is, to get a proper wage, minimum wage component + decent living needs + economic growth. Since home-based workers do 
not have minimum wage, either provincial, municipal, or sectoral, the researcher proposed the wage formula for home-based workers as follows. Assuming the facts that wage received by home-based workers is 1,000 IDR per piece, they produce 30 pieces per day, they work for one week or approximately 40 hours, and the inflation is $5 \%$, then 1,000 IDR x 30 x 40 hours = 1,200,000 IDR + 60,000 IDR. Thus, their salary is $1,260,000$ IDR.

Wage per piece $\mathrm{x}$ units produced $\mathrm{x}$ work hour $(40$ hours/week) + inflation and economic growth

Determination of wages especially for home-based workers is ideally calculated based on decent living needs adjusted with wages received by home-based workers. If the wage is calculated per piece, it is adjusted to the minimum price required by home-based workers. Decent living needs should be evaluated every maximum annual period (once a year) as determined in the Regulation of Minister of Manpower concerning Achievement Stages for decent living needs.

The main objective of law is essentially to create public order and balance, which is the objective of labor law (28) particularly in proper wage. The objective will be realized if every social relationship does not contradict with the provisions of applicable legal regulations and norms. Law regulates the balance between rights and obligations of humans as social beings and manifests justice in living with others. Labor law can be seen from two perspectives: labor law definition and labor law philosophy, in which the latter is the basis of the formation of a legal rule that relies on the objectives of labor law, namely to uphold justice.

The low appreciation and recognition for the position of workers, especially home-based workers, in the economic system of some regions in Indonesia make their fate neglected. The life of home-based workers deserves the attention of all parties: entrepreneurs, government (executive and legislative), and other social institutions. Without the support of other involved parties, significant changes to the welfare of home-based workers will not be possible.

There are several factors that cause the low welfare of home-based workers in several regions in Indonesia; one of the indicators is the wages they receive. Every worker expects receiving wages that can adequately fulfill their and their family's needs based on humanity values. The amount of the wages cannot be determined permanently because the concept of need is dynamic, floating along the development. The most important thing is "the fulfillment of home-based workers' living needs in a natural and humane way".

The crucial issue related to a policy of proper minimum wage that can be spent to meet the needs of home-based workers and their families is the strong stigma of employers, including the government (legislative and executive), that workers including home-based workers in Indonesia is less educated, less skilled, less productive, not to mention other negative stigma. This causes the wage policy system for home-based workers to be categorized as low, not meeting their expectations.
The phenomenon of low wages is not only caused by a lack of recognition for and low position of workers in the Indonesian economic system but also caused by the annual increase of new workforce, outnumbering job availability. This condition is more profitable for employers. A home-based worker who refuses low wages from his employer will automatically stop working, or not be given a job. Employers will not be affected by their decision of quitting or resigning because they are not obliged to provide severance pay or other compensation

The condition above makes the position of home-based workers weak and helpless, being subordinates in their position. Symptoms like this will continue, becoming a permanentized view or labeling that home-based workers are low, unqualified, unskilled, uneducated, unproductive, and so on. Therefore, a more systematic and continuous effort is needed to foster a better awareness in understanding and addressing the existence of home-based workers in several regions in Indonesia, so that the paradigm or thought that positions home-based workers as "low laborers" can be minimized. Many employees are underpaid (32).

The policy of proper wage for home-based workers can ideally be made by looking not only from one perspective but also from other perspectives such as the fundamental or philosophical, normative, historical, economic, and socio-anthropological aspects. Policies made through such a way can prevent various problems in the future. Conversely, if policies are made based on a single poit of view, it is likely, or it can even be ascertained, that many new problems will arise from the policy, and the negative impact of the new problems can be greater than the existing conditions and problems that have existed so far (33).

There have been many paradigm shifts in the wage system in Indonesia, from Minimum Physical Needs to Minimum Living Needs. The change was born from a comprehensive thought evaluation about the policy. After some times of implementation, minimum physical needs paradigm was considered no longer compatible with the development of life. The change from minimum physical needs paradigm to minimum living needs paradigm (34) (13)of course, has gone through in-depth evaluations, covering all aspects of the consequences, and the new paradigm was considered the best to be applied (35).

The explanation of Government Regulation Number 8 of 1981 contains a formula for minimum wages. This minimum wage problem started to receive attention in countries that want to protect workers from arbitrary acts of employers. The first country that uses the minimum wage is New Zealand, as mentioned in an act, the Arbitration and Industrial Conciliation Act of 1894. Under the act, the arbitration court has the authority to decide on minimum wage provisions. After New Zealand, Australia and Europe followed it using minimum wage approach, i.e. France in 1915, Norway in 1918, Germany in 1923, Spain in 1926, and Belgium in 1934.

Home-based workers need to be given legal protection in accordance with their rights 
and obligations as other formal workers. Article 1 paragraph 3 of the Indonesian Constitution clearly states that Indonesia is based on law. Therefore, there is no bargaining or other alternative that law state principle must be truly implemented. Indonesia as a law state means that all actions, whether carried out by the people or the authorities, must be based on applicable law. Everything must be based on legal provisions. The state welfare law theory is used to provide legal protection for every citizens, including providing legal protection for home-based workers in obtaining jobs and rewards fairly and properly in employment relations. Legal protection provided by the state is the responsibility of the legal state to its people, in addition to realizing prosperity and providing legal protection for its citizens. Therefore, in the implementation of law state principle in regards to the implementation of national development, labor has an important role and position as an actor of national development objective. Governments have also begun to pay attention to issues related to the rights of foreign domestic workers (36). Legal protection for home-based workers is intended to ensure that the rights of home-based workers are equal to those of other formal workers. This legal protection is intended to ensure all basic rights for the welfare of workers and their families by maintaining the development of the business world. Based on these considerations, the inherent rights of home-based workers must be protected as the rights of formal workers in general, especially the right for proper wage (30).

The principle of right equality to obtain employment and fair treatment from employers is contained in Article 27 paragraph 2 and Article 28D paragraph 2 of Indonesian Constitution. The two articles state that every citizen has the right to get a job and get compensation fairly and properly from a work relationship. The provisions as stated in Article 27 paragraph 2 and Article 28D paragraph 2 of Indonesian Constitution above contain labor law politics (37).These special arrangements can create rules that actually protect everyone's right to work and protect everyone in their work. Law politics is more concerned with enactment policy by ignoring basic policy. Law politicsis a policy taken by policy makers through authorized officials and institutions, in this case the state, to establish laws that need to be replaced, changed, or maintained, and laws that need to be regulated or issued so that state administration and governance can take place well and orderly. The existence of this policymakes the goals of the state, which is gradually improving the welfare of its people according to plan, can be achieved (38).

The politics of law is useful to find laws suit expectations and reality (das sein das sollen), suit the articles and the implementing regulations, and suit law in book and law in action (39) (40). The objectives of labor law politics are (41)as follows.

1. The main objective of law politics is to ensure justice in society;

2. In addition to guaranteeing justice, law politics also creates peace of life by maintaining legal certainty;
3. Law politics also aims to handle real interests in coherent coexistence.

The legal protection from the power of employer will be established if the legislation in the labor which requires or forces the employer to act as in the legislation is really carried out by all parties. Legal protection is always related to power. There are two kinds of power that are always the center of attention, namely the power of legal protection for the people (who are governed) against the government (the one who rules) (30). Legal protection for home-based workers is very necessary since theirstatus or legal position is weak (inferior), while the status or legal position of employersis strong (superior).

\section{CONCLUSION}

Home-based workers are people with rights and obligations guaranteed by the constitution through Article 27 paragraph 2 and Article 28D paragraph 2 of Indonesian Constitution. Every human being wants to be treated as one through existing policies, including policies related to proper wage for home-based workers.

Employers are responsible for guaranteeing the position of workers, who are inferior. The legal status of home-based workers is very weak compared to workers in general. Therefore, home-based workers must receive legal protection in accordance with their position as stipulated in labor law. Wage for workers, especially home-based workers, is ideally calculated based on decent living needs adjusted with the wages received by home-based workers. If the wage is calculated per piece, it is adjusted to the minimum price required by home-based workers. Decent living needs should be evaluated every maximum annual period (once a year) as determined in the Regulation of Minister of Manpower concerning Achievement Stages for decent living needs.

There are several factors that cause the low welfare of home-based workers in several regions in Indonesia; one of the indicators is the wages they receive. Every worker expects receiving wages that can adequately fulfill their and their family's needs based on humanity values. The amount of the wages cannot be determined permanently because the concept of need is dynamic, floating along the development. The most important thing is "the fulfillment of home-based workers' living needs in a natural and humane way" Increasing the skill of home-based workers to change the negative stigma that they are low, unqualified, unskilled, uneducated, unproductive, and so on are needed, in addition to more systematic and continuous efforts to foster a better awareness in understanding, interpreting, and responding to the existence of home-based workers in several regions in Indonesia. Thus, the presumption that positioned home-based workers as "low laborers" can be minimized. 


\section{ACKNOWLEDGEMENT}

The highest gratitude is addressed to the United State Agency for International Development (USAID) through the Sustainable Higher Education Research Alliance (SHERA) Program for Universitas Indonesia Scientific Modeling, Application, Research and Training for City-centered Inovation and Technology (SMART CITY) Project

\section{REFERENCES}

[1] LUND, Francie, Hierarchies of care work in South Africa: Nurses, social workers and home-based care workers. 2010, Wiley Riset Academi, pp. Pages 495-509.

[2] Agusmidaha, Suria Ningsiha,Erna Herlinda, Rancangan Peraturan Daerah Bagi Perlindungan Pekerja Rumahan (PR), Formalisasi yang Diragukan. 2018, TALENTA Conference Series, pp. 089-097.

[3] Pratomo, Devanto Shasta Does minimum wage affect hours worked of paid employment in Indonesia? 5, 5 6, 2014, International Journal of Social Economics, Vol. 41, pp. 362-379.

[4] Susanti, E , Efektivitas Upah Minimum di Kabupaten Bandung. 2017, Jurnal Manajemen Pelayanan Publik. DOI 10.24198/jmpp.v1i1.13566.

[5] Sholeh, Maimun, Permintaan Dan Penawaran Tenaga Kerja Serta Upah :. 1, 2007, Jurnal Ekonomi \& Pendidikan, Vol. 4, pp. 62-75.

[6] Shasta, Pramoto Devanto, Kebijakan Upah Minimum Untuk Perekonomian Yang Berkeadilan: Tinjauan UUD 1945. 2, 2011, Journal of Indonesian Applied Economic Universitas Brawijaya, Vol. 5, pp. 269-284.

[7] Yuvita A Mangesti, Bernard L. Tanya. Moralitas Hukum. Yogyakarta : Genta Publishing, 2014.

[8] Wijayanti, Asri. Menggugat Konsep Hubungan Kerja. Bandung : CV. Lubuk Agung, 2011. pp. 210-217.

[9] Pamudji. Kepemimpinan Pemerintahan di Indonesia. Jakarta : Bina Aksara, 1982. p. 25.

[10] Budiardjo, Miriam. Dasar-dasar Ilmu Politik. Jakarta : Gramedia Pustaka Utama, 1991.

[11] Indonesia, Republik. Undang-Undang Dasar Negara Republik Indonesia. Jakarta : Indonesia, 2004.

[12] Marilyn Carr, Martha Alter Chen \& Jane Tate, Globalization and Home-Based Workers. 3, 2010, Globalization and Home-Based Workers, Feminist Economics,, Vol. 6, pp. 123-142. ISSN: 1354-5701 (Print) 1466-4372 (Online.

[13] Agusmidah. Hak Ekonomi Perempuan: Pekerja Rumahan dalam Jangkauan Undang-Undang Ketenagakerjaan. 1, Medan: Talenta Publisher Universitas Sumatera Utara, 2019, Talenta Conference Series: Local Wisdom, Social, and Arts (LWSA), Vol. 1, pp. 001-007. 2654-7058.

[14] Sofiani, Triana, Eksistensi Perempuan Pekerja Rumahan Dalam Konstelasi Relasi Gender. 1, Pekalongan : Pusat Studi Gender dan Anak (PSGA) IAIN Pekalongan, 2012, Jurnal Kajian Gender Muwazah, Vol. 2, pp. 197-204. ISSN 2502-5368.

[15] Suci Flambonita, Abdul Rachmad Budiono, Iwan Permadi, Abdul Madjid, The Concept of Proper Wages for Workers Based on So cial Justice. s.1. : JLPG IISTE, 2019, Journal of Law, Policy and Globalization, Vol. 82, pp. 96-102. ISSN 2224-3240 (Paper) ISSN 2224-3259 (Online).

[16] Shalini, Martha A Chen and Home-based workers and cities, s.l. : www.sagepublication.com, october 2016, Environment and Urbanization, Vol. 28, pp. 343-358. 17460301.

[17] Riyanto, Pancasila Dasar Negara Indonesia. 3, 2017, Jurnal Hukum \& Pembangunan, Vol. 37, p. 151. 0125-9687.

[18] Nur Ida Iriani, HS.Lilik Wiyanto, Pemberdayaan Kelompok Pekerja Rumahan Melalui Pembinaan Kewirausahaan Dalam Upaya Mengentas Kemiskinan. 3, s.1. : www.publikasi.unitri.ac.id, 2016, JISIP: Jurnal Ilmu Sosial dan Ilmu Politik, Vol. 5, pp. 104-106. ISSN 2442-6962.

[19] Husni, Lalu. Pengantar Hukum Ketenagakerjaan Indonesia . Jakarta : PT. RajaGrafindo Persada, 2003.

[20] Uwiyono, Aloysius. Asas-asas Hukum Perburuhan. Jakarta : PT. Rajawali Press, 2014.

[21] Skedinger, Per, Employment effects of union-bargained minimum wages. 5 , http://www.emeraldinsight.com/doi/10.1108/IJM-02-2013-0037, 83 , 2015, International Journal of Manpower, Vol. 36, pp. 694-710.

[22] Bhorat, Haroon, Estimating the impact of minimum wages on employment, wages, and non-wage benefits: The case of agriculture in South Africa. 2014, American Journal of Agricultural Economics.

[23] Magruder, Jeremy R, Can minimum wages cause a big push? Evidence from Indonesia.. 1, s.l. : ELSEVIER, 2013, Journal of Development
Economics,

Vol.

100

https://doi.org/10.1016/j.jdeveco.2012.07.003.

[24] Iskandar, Pranoto, The Pancasila Delusion. 4, s.l. : Taylor \& Francis Online, 2016, Journal of Contemporary Asia, Vol. 46, pp. 723-735. 17527554, https://doi.org/10.1080/00472336.2016.1195430.

[25] Minnite, Lorraine C. Welfare. International Encyclopedia of the Social \& Behavioral Sciences: Second Edition. 2015.

[26] Carter, Thomas J. Minimum wage laws: what does an employment increase imply about output and welfare? 4, s.l. : North-Holland, 91 , 1998, Journal of Economic Behavior \& Organization, Vol. 36, pp. 473-485. DOI 10.1016/S0167-2681(98)00107-3.

[27] Mampu. Perlindungan pada Pekerja Rumahan Bisa Dalam Bentuk Perda Malang :

http://suryamalang.tribunnews.com/2016/12/20/perlindungan-pada-pek erja-rumahan-bisa-, 2016.

[28] Damanhuri, Bahrudin, Legiani W Rahman. Implementasi Nilai-Nilai Pancasila Sebagai Upaya Pembangunan Karakter Bangsa. 2016, Untirta Civic Education Journal. ISSN 2541-6693.

[29] Sulistiawati, Rini, Pengaruh Upah Minimum Terhadap Penyerapan Tenaga Kerja dan Kesejahteraan Masyarakat di Provinsi di Indonesia. 3, Pontianak : s.n., Oktober 2012, EKSOS, Vol. Volume 8, pp. 195-211. ISSN 1693 - 9093.

[30] Lester, R, Employment Effects of Minimum Wages.. s.l. : https://wol.iza.org/articles/employment-effects-of-minimum-wages/long , 2006, Industrial and Labor Relations Review. ISSN 00197939, DOI $10.2307 / 2519990$.

[31] Kwon, Hyun Soo. Economic Theories of Low-Wage Work. 1, s.l. : Taylor and Francis Online, 24:1, 61-70, DOI: $10.1080 / 10911359.2014 .8446152014$, Journal of Human Behavior in the Social Environment, Vol. 24, pp. 61-70. DOI: 10.1080/10911359.2014.844615.

[32] Gorry, Minimum wages and youth unemployment. 2013, European Economic Review, Vol. Vol. 64, pp. 57-75. data access 2019-03-10. ISSN 00142921, 10.1016/j.euroecorev.2013.08.004.

[33] Saragih, Bintan Regen. Politik Hukum, (Bandung: CV. Utomo, 2006). Bandung : CV. Utomo, 2006.

[34] Sakumoto, Koesnadi Hardjasoemantri dan Naoyuki. Current Development of Laws In Indonesia. Tokyo : Institute of Developing Economies Japan Exteranal Trade Organization, 1999.

[35] Juwana, Hikmahanto. A Survey On The Influence of International Economic Policy on Indonesia Laws: Implementation and Problem. 1999.

[36] Huijber, Theo. Filsafat Hukum dalam Lintas Sejarah, (Yogyakarta: Kanisius, 1982), hlm. 118-120. YogyakartaKanisius : s.n., 1982. pp. 118-120.

[37] Midah, Agus. Dinamika \& Kajian Teori, Hukum Ketenagakerjaan Indonesia. Bogor : Ghalia Indonesia, 2010. p. 135.

[38] Hadjon, Philipus M. Perlindungan Hukum Bagi Rakyat. surabaya Universitas Airlangga Press, 2002.

[39] Sofiani, T. Manifestasi Perlindungan Hukum Berkeadilan Gender Berbasis Pemahaman Hak Dan Kewajiban Hukum Dalam Hubungan Kerja. 1, Pekalongan: Lembaga Penelitian dan Pengabdian kepada Masyarakat, IAIN Pekalongan, 5 13, 2013, Jurnal Penelitian, Vol. 5. Available at: <http://e-journal.iainpekalongan.ac.id/index. ISSN 2541-6944.

[40] Hieh-Hsuan Wang, Chien-Ping Chung,Jen-Te Hwang \&Chia-yang Ning, The Foreign Domestic Workers in Singapore, Hong Kong, and Taiwan: Should Minimum Wage Apply to Foreign Domestic Workers? C. 2018, www.tandfonline.com, pp. 154-174.

[41] Baldwin, M., \& Johnson, W. G, Estimating the employment effects of wage discrimination.. 3, s.1. : [Crossref], [Web of Science ${ }^{\circledR}$ ], 1992, Review of Economics and Statistics, Vol. 74, pp. 446-455.

[42] García-Mínguez, P., \& Sánchez-Losada, F. Statistical discrimination and growth: Should we subsidize discriminated against workers? Economics Letters. 2, s.1. : [Crossref], [Web of Science ${ }^{\circledR}$ ], [Google Scholar], 2003, Vol. 79, pp. 255-261.

[43] Hwang, J. T., Wang, C. H., \& Chung, C. P. Is it possible to decouple foreign workers wages from the minimum wage in Taiwan? 2, s.1. : [Crossref], [Web of Science (B], 2011, The Economic and Labour Relations Review, Vol. 22, pp. 107-130.

[44] Knight, T. Women and the Chinese labor market: Recent patterns and future possibilities. 3, s.1. : [Taylor \& Francis Online], [Web of Science (®), 2016, Chinese Economy, Vol. 49, pp. 213-227.

[45] Budiono, Abdul Rachmad. Hukum Perburuhan. Jakarta : PT. Indek, 2009. ISBN 979-062-048-9.

[46] Zainal Asikin, dkk. Dasar-dasar Hukum Perburuhan. Jakarta : Raja Grafindo Persada, 1993.

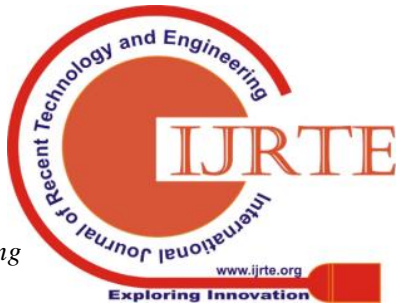


[47] Bernard L. Tanya dkk, Bernard L. Tanya dkk. Teori Hukum Strategi Tertib Manusia Lintas Ruang dan Generasi. Yogyakarta: Genta Publishing, 2010. p. 45.

[48] Black, Hendry Chambell. Black's Law Dictionary 6th Edition. St. Paul Minn: : West Publishing Co., 1990. p. 1002.

[49] Mavromaras, Wage differentials between male-female and native-foreign workers in pre-unification Germany.. 3/4, s.1. : www.emeraldinsight.com/doi/10.1108/01437720410541416, 2004, International Journal of Manpowe, Vol. 25, pp. 300-320. ISSN0143-772

[50] Benjamin, A Theory of Fairness in Labour Markets.. 2015, Japanese Economic Review. ISSN 14685876, DOI 10.1111/jere.12069.

\section{AUTHORS PROFILE}

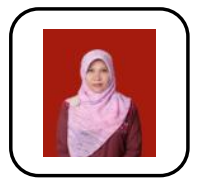

Suci Flambonita, born in Palembang, 18 Juli 1979, doctoral faculty of Law Brawijaya University and Lecture at faculty of Law Sriwijaya University Palembang, Indonesia. Publication: Wujud Perlindungan terhadap Tenaga Kerja Indonesia di Luar Negeri Dalam Prosiding Peluang dan Tantangan Hukum Ketenagakerjaan dalam Mendorong Industrialisasi yang Berlandaskan Falsafah Pancasila, (2017) (Prosiding Konferensi Ke-2 P3HKI ISBN 978-602-51249-0-7), Peran Negara dalam Menciptakan Kesejahteraan Bagi Tenaga Kerja di Indonesia (Mencermati Perpres Nomor 20 Tahun 2018 tentang Penggunaan Tenaga Asing) buku Referensi "Tenaga Kerja Asing dan Kedaulatan Negara (2018), UMM Surabaya Press ISBN 978-602-5786-03-7, The Concept of Proper Wages for Workers Based on Social Justice (2019) https://www.iiste.org/Journals/index.php/JLPG/article/view/46657 DOI: $10.7176 /$ JLPG/82-13. Research Work: Buruh yang di Upah Tidak Layak sebagai Pelaksanaan Permenakertrans Nomor 13 Tahun 2012 Tentang Standar Kebutuhan Hidup Layak (2014), Perlindungan Hukum Terhadap Hak Pekerja Perempuan di Bidang Ketenagakerjaan (2015), Perlindungan Terhadap Tenaga Kerja Indonesia di Luar Negeri oleh Pemerintah Republik Indonesia (2016),

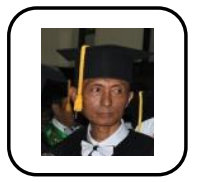

Abdul Rachmad Budiono, Lecture Faculty of Law at Brawijaya University, Malang, Indonesia Publication: Legal Relationship between Employer and Labor (2014) Body Co-Modification of Balinese Woman Dancer in Law Perspective about Pornography (2014), The Outsourcing According to Indonesian Law (2014)

Labor in Law (2014), Shariah Wage Principle within Industrial Relation (2014), The Implementation of Principle of Integration in Fulfilling the Worker's Rights of Bankrupt Company as a Medium of Law to Solve Debt Problems Fairly, Quickly, Openly, and effectively (2017), Research work: Penyimpangan Pelaksanaan Outsourcing Menurut UU No. 13 Tahun 2003 tentang Ketenagakerjaan (2014), Penetapan sebagai salah satu syarat Pemutusan Hubungan Kerja Tanpa Persetujuan Pekerja (2015), Model Penyelesaian Pemutusan Hubungan Kerja Massal Atas Alasan Bersifat Ekonomi Dalam Upaya Mewujudkan Kondisi Hubungan Industrial Yang Harmonis (2016) 